\title{
Pengembangan Ekonomi Kreatif: Mengubah Sampah jadi Berkah
}

\author{
https://doi.org/10.25008/parahita.v1i1.40 \\ Meiliyah Ariani $^{1 *}$, Koento Hariono ${ }^{2}$, Zulhawati ${ }^{3}$ \\ ${ }^{1,2}$ Fakultas Ekonomi dan Bisnis, Universitas Prof. Dr. Moestopo (Beragama) \\ Jl. Hang Lekir I No. 8, Jakarta 10270 - Indonesia \\ ${ }^{3}$ Fakultas Bisnis, Psikologi dan Komunikasi, Universitas Teknologi Yogyakarta \\ Jl. Ring Road Utara, Mlati Krajan, Yogyakarta 55285 - Indonesia \\ *Email Korespondensi: meiliyahariannie@yahoo.co.uk
}

\begin{abstract}
Abstrak
Pemuda merupakan penggerak perekonomian negara, salah satunya melalui industri kreatif, sehingga mereka harus disiapkan agar bisa bersaing menghadapi pemuda mancanegara seiring dengan telah berlakunya Masyarakat Ekonomi ASEAN (MEA). Industri kreatif mampu mendongkrak perekonomian dan menciptakan lapangan kerja, selain memunculkan peluang bisnis baru bagi generasi muda Indonesia. Kegiatan pengabdian kepada masyarakat ini bertujuan untuk membangun jiwa bisnis para pemuda dengan karakter tangguh dan kreatif melalui pendidikan kewirausahaan demi mengembangkan industri kreatif. Kegiatan tersebut dilakukan menggunakan metoda ceramah, tutorial, diskusi serta pendampingan berkelanjutan yang diakhiri dengan evaluasi penyusunan rencana usaha kreatif. Kegiatan disikapi positif oleh para peserta. Mereka antusias mengikuti proses kegiatan dan menghasilkan karya kreatif berupa tas, tempat pensil, dompet yang dari limbah sampah plastik. Hasil kreatif anak-anak muda itu didistribusikan ke pasar industri kreatif yang tersebar di berbagai kawasan. Kata kunci: Kewirausahaan, ekonomi kreatif, sampah, pemuda, MEA
\end{abstract}

\section{PENDAHULUAN}

Indonesia akan mengalami Bonus Demografi antara tahun 2020 - 2030 dengan penduduk usia produktif antara 15-64 tahun mencapai 70\% dari total jumlah penduduk, atau setara dengan 180 juta jiwa. Kondisi itu membawa konsekwensi sosial-ekonomi bagi perekonomian nasional. Bonus Demografi bisa menjadi berkah bagi pembangunan untuk memajukan kesejahteraan serta kemakmuran bagi masyarakat apabila negara dapat menciptakan lapangan pekerjaan bagi angkatan kerja, sehingga dapat memberikan kontribusi bagi perekonomian nasional. Sebaliknya, akan menjadi beban apabila negara gagal memanfaatkan bonus demografi tersebut. Oleh sebab itu, untuk mendapatkan manfaat bonus demografi, perlu usaha bersama dari seluruh lapisan masyarakat serta lembaga terkait.

Peran pemuda dan masyarakat dalam kemajuan perekonomian bangsa sangat dibutuhkan. Pemuda memegang peran penting sebagai motor penggerak perekonomian masa depan. Pemuda harus disiapkan sejak dini agar dapat bersaing dengan individu-individu lain dari luar negeri. Tantangan baru muncul dengan adanya Masyarakat Ekonomi ASEAN (MEA) 2015. Keberadaan MEA membuat arus lalu lintas barang, jasa, investasi, dan modal di kawasan Asia Tenggara menjadi bebas.

MEA membuat persaingan ekonomi semakin ketat. Indonesia harus menggali sumber ekonomi alternatif bagi kemajuan dan kesejahteraan masyarakat. Salah satu solusinya dengan ekonomi kreatif atau industri kreatif. Banyaknya sumber daya alam di Indonesia menjadi faktor utama untuk meningkatkan perekonomian bangsa melalui industri kreatif. Saat ini dunia telah memasuki era industri gelombang keempat, yaitu industri kreatif yang menempatkan kreativitas dan inovasi sebagai penggerak pertumbuhan ekonomi.

Kegiatan perekonomian di era ekonomi kreatif digerakkan oleh industri kreatif. Di sejumlah negara, industri kreatif mampu mendongkrak perekonomian dan menciptakan 
lapangan kerja, selain memunculkan banyak peluang bisnis baru. Di beberapa negara, seperti Inggris, sumbangan industri kreatif terhadap PDB mencapai 7,9\%, melampaui pendapatan dari sektor industri manufaktur yang hanya 5\%. Pertumbuhannya rata-rata $9 \%$ per tahun, jauh di atas rata-rata pertumbuhan ekonomi negara maju yang berkisar 2-3\%. Di Australia, industri kreatif menyumbang sekitar 3,3\% terhadap PDB dengan rata-rata pertumbuhan per tahun mencapai 5,7\% (Simatupang, 2008).

Banyaknya peluang dan bertumbuhnya industri kreatif harus dimanfaatkan dengan baik. Khususnya untuk generasi muda yang menjadi penggerak perekonomian bangsa. Namun, saat ini masih banyak pemuda yang belum sadar akan peran penting yang harus diembannya untuk masa depan bangsa. Jumlah generasi muda Indonesia banyak adalah potensi untuk pembangunan bangsa ini ke depan.

Pembangunan pemuda berkarakter tangguh dan kreatif melalui pendidikan kewirausahaan dan mengembangkan industri kreatif menjadi penting. Hal ini dapat dimulai di daerah perdesaan maupun perkotaan. Potensi sumber daya alam lokal yang menjadi bahan industri kreatif di desa lebih besar daripada di kota, sedangkan di perkotaan limbah dapat dijadikan sebagai sumber daya ekonomi kreatif bagi pemuda di berbagai kelurahan.

Kelurahan Gelora merupakan salah satu kelurahan di Kecamatan Tanah Abang, Kota Administrasi Jakarta Pusat, Provinsi DKI Jakarta. Kelurahan itu memiliki luas 259,13 ha (2,59 Km2), 732 Kepala Keluarga, 12 Rukun Tetangga dan 2 Rukun Warga. Jumlah penduduknya 2.471, terdiri laki- laki 1.234 dan perempuan 1.237. Pemuda di Kelurahan Gelora belum digerakkan membangun industri kreatif. Banyak pemuda menghabiskan waktunya untuk kegiatan yang tidak produktif.

Belum adanya pengetahuan akan kewirausahaan melalui industri kreatif serta tidak adanya pendampingan dari pihak-pihak yang kompeten menjadi faktor yang mempengaruhi belum tumbuhnya keinginan para pemuda mendirikan usaha kreatif guna menghadapi persaingan global. Untuk itu dibutuhkan sosialisasi, pelatihan, serta pendampingan agar mereka dapat membangun usaha kreatif sehingga bisa meningkatkan perekonomian masyarakat di Kelurahan Gelora.

Pelatihan ini diarahkan untuk memanfaatkan limbah sampah yang tersebar di sekitar lokasi kelurahan dengan cara mendaur ulang sampah. Mendaur-ulang (recycling) adalah proses menjadikan bahan bekas menjadi bahan baru, sehingga sampah menjadi sesuatu yang berguna, dan mengurangi penggunaan bahan baku yang baru, mengurangi penggunaan energi, mengurangi polusi, kerusakan lahan, dan emisi gas rumah kaca jika dibandingkan dengan proses pembuatan barang baru. Saat ini, banyak hasil kerajinan dari bahan-bahan bekas, disebut kerajinan daur ulang. Salah satunya adalah kerajinan tangan eks bungkus kopi, memanfaatkan limbah bungkus kopi.

Berdasarkan permasalahan tersebut, diperlukan pelatihan kewirausahaan bagi pemuda khususnya usaha kreatif dengan memanfaatkan potensi sumber daya alam lokal maupun limbah pakai yang ada di sekitar Kelurahan Gelora.

Banyak permasalahan yang dihadapi oleh pemuda dalam membangun dan mengembangkan industri kreatif di Kelurahan Gelora. Selain itu, belum adanya pelatihan kewirausahaan disertai dengan pendampingan menjadi masalah lain yang dihadapi oleh pemuda. Hal inilah yang menyebabkan di Kelurahan Gelora belum banyak pemuda yang mendirikan usaha kreatif sehingga perekonomian di Kelurahan Gelora belum dapat dikatakan baik.

Dari permasalah tersebut, rumusan masalah dalam kegiatan ini adalah: (1) Bagaimana cara meningkatkan pengetahuan dan pemahaman pemuda di Kelurahan Gelora mengenai persaingan ekonomi global?; (2) Bagaimana menyadarkan pemuda atas peran penting pemuda bagi perekonomian bangsa?; (3) Bagaimana meningkatkan jiwa kewirausahaan pemuda di 
Kelurahan Gelora; (4) Bagaimana membuat rencana usaha kreatif bagi pemuda di Kelurahan Gelora.

Pelaksanaan kegiatan ini untuk membantu mengembangkan potensi masyarakat melalui pelatihan ketrampilan kepada masyarakat. Melalui pelatihan ini, diharapkan masyarakat di wilayah Kelurahan Gelora akan lebih terberdayakan secara sosial-ekonomi karena memiliki ketrampilan tambahan yang dapat dimanfaatkan untuk meningkatkan pendapatan. Pada gilirannya, peningkatan pendapatan yang diperoleh bisa meningkatkan kesejahteraan.

Kegiatan pengabdian Pada Masyarakat ini bertujuan untuk memberikan pengetahuan dan pemahaman tentang ekonomi global dan peran penting pemuda bagi ekonomi Indonesia di masa depan, memberikan pelatihan kewirausahaan, serta memberikan pelatihan membuat rencana usaha kreatif dan pendampingan berkelanjutan bagi pemuda di Kelurahan Gelora.

Tujuan pelatihan dalam kegiatan ini adalah: (1) untuk meningkatkan kesadaran peserta terhadap ekonomi global dan peran pemuda dalam ekonomi Indonesia di masa depan; (2) meningkatkan jiwa kewirausahaan peserta; (3) peserta mampu memilih usaha kreatif, dan (4) peserta mampu menyusun rencana usaha kreatif.

Kegiatan Pengabdian pada Masyarakat ini diharapkan dapat memberi bekal kepada para pemuda di Kelurahan Gelora sebagai generasi penggerak perekonomian Indonesia di masa depan dengan membentuk ekonomi kreatif, yaitu berbagai industri kreatif dengan memanfaatkan potensi sumber daya alam lokal maupun limbah pakai.

Pelatihan kewirausahaan khususnya untuk meningkatkan motivasi dan jiwa kewirausahaan bagi para pemuda serta penyajian berbagai jenis industri kreatif yang dilanjutkan dengan pembuatan rencana usaha diharapkan akan memberikan pengetahuan, pemahaman, serta keterampilan bagi pemuda untuk merencanakan usaha kreatif. Pendirian berbagai usaha kreatif ini diharapkan dapat meningkatkan ekonomi di Kelurahan Gelora.

Pengabdian kepada masyarakat ini menyasar para pemuda yakni anggota Karang Taruna dan ibu-ibu PKK Kelurahan Gelora sebanyak 30 orang. Penetapan sasaran merupakan upaya untuk membentuk ekonomi kreatif di Kelurahan Gelora dengan diawali pendidikan dan pelatihan, pembuatan rencana-rencana usaha kreatif oleh pemuda dan pendampingan berkelanjutan. Harapannya, peserta pelatihan dapat menularkan pengetahuan yang didapat kepada pemuda lain yang tidak tergabung dalam Karang Taruna sehingga para pemuda di Kelurahan Gelora dapat mendirikan dan mengembangkan berbagai usaha kreatif dengan memanfaatkan sumber daya alam lokal maupun limbah pakai.

Luaran pelaksanaan kegiatan ini adalah: (1) Peserta mendapatkan pengetahuan tentang perekonomian global serta peran pemuda dalam membangun perekonomian Indonesia. Peserta juga dimotivasi agar memiliki kesadaran kewirausahaan dan membangun usaha kreatif; (2) Peserta pelatihan mendapatkan materi tentang perencanaan usaha kreatif dengan pemanfaatan sumber daya alam lokal, mulai dari menganalisis peluang usaha sampai penentuan produk, pengelolaan keuangan, serta pemasarannya; (3) Peserta pelatihan mendapatkan kesempatan mendiskusikan permasalahan yang berkaitan dengan pembuatan rencana usaha hingga mampu membuat rencana usaha yang baik; (4) Peserta mampu membuat rencana usaha kreatif agar mereka dapat membangun usaha-usaha kreatif guna meningkatkan ekonomi daerah serta mempersiapkan diri untuk menghadapi persaingan global melalui ekonomi kreatif.

\section{METODE PELAKSANAAN}

Kegiatan ini dilakukan dengan menggunakan metoda ceramah, tutorial, diskusi, pendampingan berkelanjutan dan evaluasi.

Metoda Ceramah. Peserta diberikan pengetahuan tentang perekonomian global serta peran pemuda dalam membangun perekonomian Indonesia di masa depan. Peserta juga diberikan motivasi agar memiliki kesadaran akan pentingnya kewirausahaan bagi ekonomi Indonesia, 
khususnya di Kelurahan Gelora sehingga jiwa wirausaha peserta dapat meningkat dan memiliki keinginan untuk mendirikan dan membangun usaha kreatif.

Metoda Tutorial. Peserta pelatihan diberikan materi tentang perencanaan usaha kreatif dengan pemanfaatan sumber daya alam lokal maupun limbah pakai, mulai dari menganalisis peluang usaha sampai dengan penentuan produk, pengelolaan keuangan, serta pemasarannya.

Metoda Diskusi. Peserta pelatihan diberikan kesempatan untuk mendiskusikan permasalahan yang berkaitan dengan pembuatan rencana usaha yang dihadapi oleh peserta sehingga peserta mampu membuat rencana usaha yang baik.

Kegiatan Pengabdian pada Masyarakat ini dievaluasi untuk mengetahui seberapa jauh keberhasilan dari kegiatan tersebut yang selengkapnya disajikan pada Tabel 1:

Tabel 1. Rancangan Evaluasi

\begin{tabular}{|c|c|c|}
\hline Tujuan & Indikator Ketercapaian & Tolok Ukur \\
\hline $\begin{array}{l}\text { Peserta termotivasi untuk } \\
\text { berwirausaha. }\end{array}$ & $\begin{array}{l}\text { Peserta memiliki keinginan untuk } \\
\text { berwirausaha dengan memanfaatkan } \\
\text { sumber daya alam lokal maupun } \\
\text { limbah pakai. }\end{array}$ & $\begin{array}{l}\text { Peserta memilih jenis-jenis } \\
\text { usaha kreatif yang mungkin } \\
\text { didirikan dengan pemanfaatan } \\
\text { sumber daya alam lokal } \\
\text { maupun limbah pakai. }\end{array}$ \\
\hline $\begin{array}{l}\text { Peserta mengetahui dan } \\
\text { memahami } \\
\text { kewirausahaan serta } \\
\text { mampu menyusun } \\
\text { rencana usaha. }\end{array}$ & $\begin{array}{l}\text { Peserta memahami kewirausahaan } \\
\text { dan mampu menyusun rencana usaha } \\
\text { dengan memanfaatkan sumber daya } \\
\text { alam lokal maupun limbah pakai. }\end{array}$ & $\begin{array}{l}\text { Peserta menyelesaikan rencana } \\
\text { usaha kreatif. }\end{array}$ \\
\hline $\begin{array}{l}\text { Peserta mengaplikasikan } \\
\text { rencana usaha menjadi } \\
\text { usaha kreatif di lokasi } \\
\text { masing-masing peserta }\end{array}$ & $\begin{array}{l}\text { Peserta mampu mendirikan usaha } \\
\text { kreatif yang baru dengan } \\
\text { memanfaatkan sumber daya alam } \\
\text { lokal maupun limbah pakai. }\end{array}$ & $\begin{array}{l}\text { Peserta dapat mendirikan } \\
\text { usaha baru secara individu atau } \\
\text { kelompok. }\end{array}$ \\
\hline
\end{tabular}

\section{HASIL DAN PEMBAHASAN}

Pelaksanaan pengabdian pada masyarakat dilakukan dalam bentuk pelatihan ekonomi kreatif, mengelola limbah sampah atau mendaur-ulang (recycling) sampah bungkus kopi menjadi bermacam-macam souvenir cantik dan menarik. Keberhasilan itu memberikan manfaat bagi para pemuda dan ibu-ibu di wilayah Kelurahan Gelora. Diharapkan pelatihan ini menjadi keterampilan tambahan tentang pemanfaat limbah sampah dan peningkatan pendapatan bagi masyarakat di wilayah kelurahan Gelora, Jakarta Pusat.

Dalam kegiatan persiapan ini dilakukan pertemuan dengan pihak Kelurahan Gelora untuk menyampaikan maksud dan rencana kegiatan (konsep) pengabdian pada masyarakat kepada Pemda pada tingkat kelurahan selaku pengelola wilayah setempat. Selain itu juga dilakukan koordinasi melalui pertemuan maupun komunikasi dengan pihak konsultan dalam rangka saling berbagi ide gagasan serta pemikiran guna mempertajam capaian hasil antara dalam rangka penyamaan persepsi maupun pengawalan kegiatan di atas.

Setelah koordinasi tercapai, kegiatan selanjutnya adalah mobilisasi warga oleh pihak kelurahan guna menyampaikan sosialisasi rencana pengabdian kepada masyarakat pada lokasi yang telah ditentukan. Setelah masyarakat memahami dan menyepakati waktu pelaksanaannya, pihak kelurahan, selanjutnya, mengumpulkan pemuda dan masyarakat di tempat yang disediakan pada hari dan waktu yang telah ditentukan untuk pelaksanaan pelatihan dalam rangka pengabdian masyarakat.

Kegiatan dilaksanakan di Gedung Serbaguna Kelurahan Gelora di RW 02, pada 28 Februari 2018 dan berlangsung mulai dari pukul 13.00 sampai dengan pukul 17.00. Acara dibuka oleh Dekan FEB-UPDM (B), dilanjutkan dengan sambutan wakil pihak Kelurahan Gelora. Pelaksanaan kegiatan dibagi menjadi dua tahap: (1) tahap pelatihan dan perbaikan mutu produk dan (2) tahap komersialisasi hasil penelitian. Tahap pelatihan dan perbaikan mutu 
produk, diawali dengan induksi oleh seorang instruktur dan untuk pertemuan-pertemuan selanjutnya, dilakukan sendiri oleh kelompok yang bersangkutan dengan laporan pihak kelurahan dan kunjungan pembinaan dan terjadwal yang akan dilakukan oleh pihak Fakultas Ekonomi dan Bisnis Universitas Prof. Dr. Moestopo (Beragama) dengan pihak Kelurahan Gelora dan warga masyarakat di kelurahan Gelora.

Seorang instruktur melatih 10 warga, sehingga dengan 3 orang instruktur, 30 warga dapat ditangani secara intens. Diharapkan, diantara 30 orang peserta pelatihan tersebut akan muncul beberapa orang sebagai Champion. Selanjutnya, para Champion tersebut dapat berbagi pengetahuannya kepada warga Kelurahan Gelora yang belum sempat mengikuti pelatihan, namun berminat untuk mendapatkan ketrampilan di atas.

Untuk sampai pada komersialisasi hasil pelatihan diperlukan pembekalan materi terkait pemasaran. Setelah pelatihan mengenai perbaikan mutu dinilai mencukupi untuk dikomersialkan, maka peserta pelatihan dibekali dengan rencana pemasaran. Materi pelatihan diarahkan pada upaya pemasaran mandiri melalui internet. Ada beberapa aplikasi yang diperkenalkan pada peserta pelatihan.

Dari hasil pelaksanaan pelatihan ekonomi kreatif dalam pengelolaan limbah sampah atau mendaur-ulang (recycling) sampah bungkus kopi menjadi bermacam-macam souvenir menunjukkan adanya minat yang sangat besar. Hal tersebut ditandai dengan antusiasnya para pemuda dan ibu-ibu mempraktekkan pembuatan souvenir dari limbah sampah menjadi bermacam-macam jenis souvenir yang menarik. Dan banyaknya pertanyaan yang diajukan, para pemuda dan ibu-ibu bisa menjalankan proses finishing dan pemasaran atas hasil yang sudah dibuat tersebut.

Para peserta meminta agar pelatihan lanjutan dan pembinaan terhadap peserta yang menjadi Champion dilakukan secara berkelanjutan. Setelah pelaksanaan pelatihan ekonomi kreatif dilakukan, dilaksanakan evaluasi dan pendampingan secara berkelanjutan dengan jadwal yang disepakati oleh pemuda dan masyarakat di Keluarahan Gelora, Jakarta Pusat.

\section{KESIMPULAN}

Pelatihan kewirausahaan ekonomi kreatif yang diselenggarakan telah memberikan tambahan ketrampilan dan pengetahuan kepada para pemuda dan ibu-ibu di kelurahaan Gelora Jakarta guna pengembangan ekonomi kreatif dengan mengubah limbah sampah secara positif yaitu daur ulang bungkus kopi. Kegiatan ini disikapi positif oleh para peserta, terlihat dari antusiasme mereka yang banyak bertanya mengenai proses pembuatan sampai pemasarannya. Para peserta juga meminta pelatihan itu dilanjutkan dan diselenggarakan secara berkelanjutan.

\section{Daftar Pustaka}

Ade, S, Fitranty. (2011). Mengembangkan Industri Kreatif Berbasis Local Wisdom dengan Pendekatan Triple Helix. Bandung: IPB.

Aditya, I. (2015), Industri Kreatif Perlu Digenjot, Yogyakarta: KR

Andriany, M. (2013). Pemberdayaan Pemuda Melalui Program Kewirausahaan Pemuda Publik, Jurnal S-1 Ilmu Administrasi Negara, 2(1).

Departemen Perdagangan RI, (2008), Pengembangan Ekonomi Kreatif Indonesia 2025: Rencana Pengembangan Ekonomi Kreatif Indonesia 2009 - 2015.

Endriati, F. (2009), Potensi Ekonomi Industri Kreatif di Provinsi DKI Jakarta: Suatu Tinjauan Input Output Tahun 2007, Universitas Indonesia.

Gugup, K. (2001). Pengantar Bisnis. Yogyakarta: BPFE. 
Hutagalung, I \& Ritonga, R. (2018). Pengaruh Iklim Komunikasi dan Komitmen Organisasi terhadap Kepuasan Kerja Pegawai Kecamatan XYZ Bekasi, Jurnal Kajian Komunikasi, 6(2), $72-84$.

Puspa, R., \& Siti, C. (2010), Pengembangan Ekonomi Kreatif Berbasis Kearifan Lokal oleh Pemuda Dalam Rangka Menjawab Tantangan Ekonomi Global, Jurnal UI untuk Bangsa Seri Sosial dan Humaniora, Vol 1.

Ritonga, R. (2014). Pertarungan Makna pada Konvensi Parti Demokrat dalam Mencari Calon Presiden Republik Indonesia Jurnal Komunikasi: Malaysian Journal of Communication, 30(2), 202-220.

Ritonga, R., Nugroho, E., Handoko, D. (2019). Struggle of Meaning and the Jokowi Myth in the 2018 Asian Games Opening Video, Jurnal Komunikasi: Malaysian Journal of Communication, 35(1), 137-155.

Simatupang, T.M. (2008). Industri Kreatif Indonesia. Bandung: Sekolah Bisnis dan Manajemen, Institut Teknologi Bandung 